\title{
SUPERVISORS PERFORMANCE OF BASIC SCHOOL IN THE TIME OF COVID-19 IN SUBANG
}

\author{
Fitria Zulfa \\ Universitas Islam Negeri Sunan Gunung Djati Bandung, Indonesia \\ fitriazulfa16793@gmail.com
}

\begin{abstract}
The Covid-19 virus outbreak has had a significant impact on various aspects of life. For the world of education, this impact occurs in the aspect of educational supervision as happened to the performance of supervision in the Subang sub-district, Subang district. The study aims to describe the performance of supervisors during the Covid-19 period and its impact on the quality of Islamic education learning in elementary schools in Subang district. The type of research used is qualitative with a case study approach. The data was collected by means of observation, interview, literature study and documentation techniques. The results showed that the performance of primary school supervisors in Subang district during the Pandemic was carried out through a remote surveillance system namely by using Whatsapp Groups. Supervision activities carried out include coaching, making LKH reports, RKB, Home Study Activity Reports and Assessment of Employee Performance Targets. Even though the Whatsapp Group media has a number of deficiencies in its application to the remote surveillance system, in the midst of a pandemic, education supervision in the elementary school environment of the Subang sub-district continues, because after all the education process in Indonesia must run optimally.
\end{abstract}

Keywords: Supervisors Performance, Basic School, Covid-19.

\section{Abstrak}

Mewabahnya virus Covid-19 telah membawa dampak signifikan terhadap keberlangsungan berbagai aspek kehidupan. Bagi dunia pendidikan, dampak yang turut dirasakan akibat virus ini salah satunya adalah adanya hambatan dari segi pengawasan pendidikan terutama dalam optimalisasi kinerja pengawas Sekolah Dasar di wilayah kecamatan Subang kabupaten Subang yang pada akbirnya berimbas kepada mutu pembelajaran di sekolah. Penelitian bertujuan untuk mendeskripsikan mengenai kinerja pengawas pada masa Covid-19 dan dampaknya terhadap mutu pembelajaran PAI pada Sekolah Dasar di kecamatan Subang. Jenis penelitian yang digunakan adalah kualitatif dengan pendekatan studi kasus. Pengumpulan data dilakukan dengan teknik observasi, wawancara, studi kepustakaan dan dokumentasi. Hasil penelitian menunjukkan bahwa kinerja Pengawas sekolah dasar di kecamatan Subang pada masa Pandemi dilakukan dengan sistem pengawasan jarak jauh melalui pemanfaatan Whatsapp Grup. Kegiatan pengawasan yang dilakukan meliputi pembinaan, membuat laporan LKH, RKB, Laporan Kegiatan Belajar di Rumah dan Penilaian Sasaran Kinerja Pegawai. Kegiatan pengawasan pada masa Covid-19 secara umum dinilai masih kurang efektif dan berpengaruh pada mutu pembelajaran di sekolah yang menjadi kurang optimal.

Kata kunci: Pengawasan, Pembelajatan, Covid-19.

\section{INTRODUCTION}

The implementation of education in schools involves various parties such as supervisors, school principals, teachers, students and so on. These parties are required to carry out their main duties and functions according to their respective positions and continue to work together in providing education in schools so that educational goals can be achieved and 
produce quality education (Iskandar \& Wibowo, 2016).

However, along with the outbreak of the Covid-19 virus that has recently entered Indonesia, the implementation of education in schools is faced with various very serious and complex problems, one of which is related to learning problems. This has taken a lot of attention from all parties, considering that the outbreak of Covid-19 in almost all countries in the world has had a major impact on various areas of human life, be it economic, social, health, security or education (Sudrajat et al., 2020).

The situation caused by this pandemic has implications for significant changes that force the education system to adapt suddenly to carry out learning from home (Ahmad Jaelani, Hamdan Fauzi, Heti Aisah, 2020). This is certainly not an easy thing, because many educational units are not yet fully prepared to face this sudden change in the learning system. The regulations related to learning through the online system apply to all educational institutions at various levels and regions. The enactment of this rule is seen as a strategic step in an effort to control the spread of the Covid-19 virus. The face-to-face learning process by teachers and students cannot be done directly at school, but is temporarily replaced by using the Distance Learning system/online (PJJ Pembelajaran jarak jaub) (Napitupulu, 2020). The main goal is that the basic rights of students to get learning can be fulfilled. PJJ in fact does not always run optimally (Dewi, 2020; Munjiat, 2020). The readiness of school infrastructure, the ability of teachers to teach online, as well as the availability of adequate smartphones to run online learning applications, are also other problems in the distance learning process during the pandemic. Another weakness that distance learning also faces is that it creates a new problem in the form of the absence of direct supervision by the teacher (Munir, 2009).

Other obstacles faced in implementing long-distance, among others, are related to limited facilities and infrastructure, especially technology support and mastery of technology by teaching resources, students and parental support being the most important part in implementing this online based learning (Arifa, 2020).

In addition, the impact of the Covid-19 Pandemic also has an impact on the performance of school supervisors, which must also be carried out by carrying out remote supervision. This condition has become a dilemma in itself for supervisors, on the one hand supervisors are required to continue to carry out their main duties and functions to carry out supervision in schools optimally, but on the other hand they are faced with the necessity of paying attention to calls from the government to implement Social Distancing and Physical Distancing 
making supervision necessary. done remotely.

This remote surveillance is then implemented with an online system which is carried out by involving various surveillance media, one of which is by using digital communication media such as Watshapp. In fact, if you pay attention to the government's appeal regarding social restrictions, it does not absolutely mean that the monitoring process must be carried out online, therefore this appeal still opens space to be implemented directly, it's just that you must continue to apply health protocols such as wearing masks and maintaining distance. Therefore, from time to time supervisors can go directly to the field to carry out educational supervision in schools (Al-Kiyumi \& Hammad, 2020; Klijn et al., 2020).

Based on the description above, it seems that there are various educational problems faced during the Covid-19 Pandemic, including those related to the performance of school supervisors in carrying out their supervisory duties towards the assisted teachers. Whereas school supervisors are educational personnel who occupy an important position to control the quality of education in schools, especially through professional guidance activities or educational and academic supervision of teachers (Habibullah, 2013).
These various problems have been explained above, one of which occurs in the supervision activities carried out by supervisors at the elementary school education unit in the Subang district. The performance of Primary School Supervisors during the Covid-19 Pandemic in the Subang sub-district area cannot be carried out directly considering the implementation of the Social Distancing and Physical Distancing systems by the government. This online surveillance system as a substitute for direct supervision ultimately has an impact on the quality of learning in schools. This is of course a very crucial issue and worthy of being a study material for research. However, the problems faced by the world of education with regard to the current pandemic situation are serious problems facing this nation even abroad. Therefore, the continuity of the education process and education supervision in the midst of the Covid-19 pandemic must still be optimized considering the urgency of education for the progress of a nation (Muhardi, 2004).

\section{LITERATURE REVIEW}

\section{School Supervisor Performance}

The performance of school supervisors is one aspect that is an important part of realizing good quality education (Hawkins \& Dulewicz, 2009). The performance itself is the result achieved by an employee both in terms of quality and quantity in carrying out 
his job duties in accordance with the given responsibilities (Mangkunegara, 2010). From this understanding it can be understood that performance is the achievement of the results of a job that has been carried out by an employee. In relation to school supervisors, what is meant by these employees are school supervisors as supervisors in the field of education. If you refer to Permenpan RB No. 21 of 2020, that what is meant by the School Superintendent is the party that has the task and function of supervising the education unit. The term school supervisor used to be known as the Education Unit Supervisor. However, since the issuance of the Regulation of the Minister of National Education Number 12 of 2007, this designation has changed its name which is in line with the Regulation of the Minister of Administrative Reform Number 21 of 2010 to become School Supervisors. Furthermore, in the world of workforce superintendent of education, also known as the term Islamic Schools Supervisors are specifically perform supervisory duties against PAI learning in schools ranging from the level of school elementary to secondary level intermediate (Gusmadi, 2014).

The status of the school supervisor itself is a regional civil servant who is placed at the district/city or provincial level (Wibowo, 2016). The main function of school supervisors is to carry out the development of the quality of education by carrying out academic and managerial supervision activities as the primary needs of schools in order to produce competitive and superior and competitive human resources in order to realize national progress through the preparation of human resources. In addition, school supervisors also occupy important positions in terms of providing guidance to the competence of school principals and teachers (Rahmad, 2018). For this reason, in order to maximize and improve the competence of supervisors, it is necessary to carry out additional education both formally through increasing educational and non-formal qualifications through regular, tiered and integrated supervision of special education and training (Muslimin, 2016). Thus, the quality of competencies possessed by school principals will have an impact on improving the performance of supervisors in relation to coaching school principals and teachers which at a later stage will have a positive impact on improving the quality of learning in schools(Mesiono, 2019; Siahaan et al., 2020).

For improving the quality of education, school supervisors are positioned as one of the components that have an important role in it. School supervisors have a strategic role in improving teaching professionals and the quality of education (Nurmala, 2019). The competence of the performance of school 
supervisors in an effort to improve the quality of madrasah is very much needed (Yustiani, 2013). Therefore, it is not surprising that school supervisors have a significant influence on improving the professionalism of school principals and teachers in teaching in schools. This is none other than because the school supervisor is one of the parties that helps provide guidance to schools in carrying out educational development and will indirectly have an impact on the quality of learning and the quality of education. In this position, it appears that the level of effectiveness of the supervisor's performance will have an influence on the quality of good school management and the effectiveness of the continuity of teaching carried out by teachers in maximizing the teaching function and educational governance in schools.

\section{Supervision of Education in Schools}

Questioning the problem of supervision can of course be interpreted as a series of activities carried out by a person who is given certain tasks and authority to carry out coaching and an assessment of what he/she manages both individually, in groups and as an institution. Supervisory itself is se people are charged duty and responsibility to provide guidance as mentioned earlier. Departing from this definition, in relation to educational supervision it means that educational supervision is an activity carried out by supervisors of educational activities in schools. These activities are carried out to improve the quality of education in schools (Wibowo, 2016). The activities referred to generally lead to coaching, monitoring, evaluation and assessment of teaching activities and school governance. The paradigm of the gait superintendent of education be part of the integral in improving the quality of education in schools as the nature of supervision. Educational supervision is an effort to assist, foster, guide, and direct all educator resources to develop better teaching and learning situations (Beddu, 2020). Educational supervision aims to provide services and assistance for the development of teaching and learning situations carried out by teachers (Faiqoh, 2019). Thus it can clearly be interpreted that educational supervision is goal-oriented to improve learning in order to improve learning outcomes.

\section{Quality of Learning in Schools}

At first glance the word quality is not a word or speech that is difficult to understand, because this term has become everyday language (Tahir, 2017). In English, the term quality can be equated with the word "quality" which means it refers to something that is "good" for a product or service with certain characteristics. In 
Indonesian terms, the word quality has a number of meanings, including: first, a characteristic or attribute that is distinctive and different from others, secondly, the nature of goodness with a high standard limit, third, it has high goodness (Echols, 2014). From these several meanings, an understanding of quality can be drawn, which is something related to good, high characteristics that can satisfy customers.

Quality in the field of education is essential as part of the educational process. The learning process is the goal of educational organizations. Education quality is the quality of graduates and services that satisfy education-related parties (Fadhli, 2016). Then to create quality education, there are several factors, among others: (1) the charge material teaching good. Teaching materials are the main educational materials that will be delivered to students. If the material is good, then the quality of education will be achieved because of the adequacy of the provisions given to students; (2) good educational planning, namely planning maturity will be able to make the teaching process more focused and easier to achieve goals; (3) good education governance, education management will make the process of education easier in achieving its goals (4) quality education is born from quality teachers, namely the performance and professionalism of teachers and teaching will directly impact the quality of learning so as to produce quality education good quality (Mulyasana, 2011). Therefore, these components must be involved in the education process in order to get a good quality education (Muhammad Nur, Cut Zahri Harun, 2016).

Another factor that also makes a positive contribution to the quality of education is the professionalism aspect of teachers in their ability to produce highquality student output, even though from low student input. Because it is important for teachers to have a strategy in an effort to improve the quality of learning (Solikah, 2014). A teacher is required to be able to provide the best teaching for students. Professionalism is what then becomes the driving force in achieving educational goals such as good quality education. Therefore, a quality or quality school certainly needs a teacher who has qualified competencies who are able to overcome any existing learning difficulties. In addition, quality schools not only have competent teachers but also have students who have good learning achievements which is an important part of determining the success of the learning process in schools.

\section{RESEARCH METHODS}

This research is included in qualitative research. This type of research is a case study. Through the type of case study research used, this research tries to find out 
and examine and investigate various aspects of educational supervision in primary schools in Subang sub-district during the Covid-19 period.

The data collection mechanism in this study was carried out using observation, interview, literature study and documentation techniques. The observation technique is carried out by making observations of various problems under study in the research focus. Then interviews were carried out by conducting dialogues with several informants, such as school supervisors and Islamic Education teachers in Subang sub-district. This technique is intended to extract various information regarding the focus of the research problem. The literature study is carried out in order to explore various information contained in various literatures in the form of various aspects of the theory used to analyze the findings of the research results. While the documentation carried out to obtain corroborating evidence for the findings of the research findings, this document can be in the form of various archives, letters, etc. relating to the performance of elementary school supervisors in Subang sub-district.

The data analysis was carried out using descriptive-qualitative techniques by interpreting the data then analyzing it and drawing conclusions from the research results. The resulting conclusion is none other than a description of the performance of elementary school supervisors in Subang sub-district in relation to the quality of learning during the Covid-19 period.

\section{RESULTS AND DISCUSSION}

\section{Research result}

The results of the research obtained regarding the performance of elementary school supervisors during the Covid-19 period had an effect on the quality of learning in Subang sub-district, which are described in the following sub-discussions:

\section{Performance of Primary School}

\section{Supervisors in Subang District during the Covid-19 Pandemic}

Supervisory performance plays an important role for the success of learning in schools. Therefore, the supervisor's performance must run optimally. The success of supervision is the key to the success of the learning process in schools. But in reality this is not always the case, the performance of Primary School Supervisors in Subang sub-district was faced with various problems during the Covid-19 period, including the supervision activities of school principals that could not be carried out directly, but through remote supervision due to social distancing and physical distancing. that is, keeping your distance. This situation in turn has an impact on supervisory activities in schools which must also be carried out remotely 
through an online system using digital media. The implication of this remote supervision makes supervisors have to be able to adjust the pattern of supervision carried out to the situation at hand. Therefore, the transfer of the monitoring mechanism from an off-network system to an on-network system must be balanced with the readiness and maturity of planning so that surveillance can continue to be carried out and be directed even in the midst of a pandemic situation(Pujilestari, 2020).

Based on the results of interviews with elementary school supervisors in Subang sub-district for the field of Islamic religious education, the results obtained from interviews with IMS as the supervisor of PAI in Subang District are as follows:

"Supervision that can be carried out during a pandemic such as the Covid-19 pandemic outbreak as it is today, is to conduct remote surveillance. This remote surveillance is carried out using an online system such as utilizing communication tools in the form of group Whats App on smart smartphones. Almost all communications carried out during the pandemic use this medium, given the limited activities to meet in person. This is very different from usually where supervision is carried out directly to schools of the PAI teachers who are guided. In my own sub-district, there are $70 \mathrm{PAI}$ teachers in all elementary school level units in Subang sub-district that I assist, consisting of PNS and Non-PNS teachers. All of these teachers are members of the whatsapp group communication media to make it easier to provide supervision of teacher performance in relation to optimizing learning in schools during the Pandemic period".

Looking at the information from the interview results above, it can be seen that in supervising teachers in the PAI subject, the supervisor conducts his activities through the Whatsapp Group as a communication medium as well as the media used in carrying out all supervisory activities. Today the development of technology has led human life to a digitalbased lifestyle, including smartphones, which are rich in applications that can be used as a means of carrying out communication. This is not something strange considering the development of digital-based technology has penetrated various aspects of human life.

The existence of a sophisticated smartphone which contains various application features such as Whatsapp can be an option for supervisors in carrying out their work as education supervisors at the school level via a remote system. This is an opportunity for supervisors to remain committed to carrying out their duties and responsibilities for the work they are assigned. So that the pandemic situation is not something that becomes an obstacle to not carrying out these duties and responsibilities.

The Whatsapp application itself can be made in the form of a group or more commonly known as the Whatsapp Group which can accommodate several people into one community or association (Whatsapp Group). This is certainly an opportunity for school supervisors to unite the assisted teachers into one group to make it easier to 
carry out supervisory activities. Moreover, the number of teachers who are assisted is not only one person. As mentioned above, that the number of PAI teachers at the primary school level who are supervised by the supervisor in the Subang sub-district itself, there are 70 teachers, which can be seen in detail in the following table:

Table 1. The number of PAI teachers at the elementary school level in Subang district.

\begin{tabular}{cccc}
\hline No. & $\begin{array}{c}\text { PNS PAI } \\
\text { teacher }\end{array}$ & $\begin{array}{c}\text { Non PNS PAI } \\
\text { Teachers }\end{array}$ & Total \\
\hline $\mathbf{1}$ & 28 & 32 & 70 \\
\hline
\end{tabular}

Source: Data Colletion

The use of Whatsapp Groups as a medium for long-distance communication has now become an inseparable part of modern human life today. Therefore, the use of this media is a common thing for the continuity of communication between supervisors and the assisted teachers and principals. Nowadays, even the learning process is usually carried out with Whatsapp Group media, in addition to other media contained in Smartphones such as Zoom Meeting, Google Meet and so on. In fact, almost all people are familiar with these various applications.

The next information related to the performance of school supervisors in Subang sub-district during the Covid-19 Pandemic, is the result of an interview with IMS that:
"Supervision performance during this Pandemic period was not optimal enough and was deemed less effective than usual, given the many obstacles faced in provide limited surveillance only over a long distance. However, the supervisors themselves are still trying their best in carrying out their duties to supervise the teachers who are coached through the use of group Whats App media such as providing guidance and direction, instructions, and so on".

The information obtained in the interview results above illustrates that surveillance during the pandemic period was less than optimal as usual and is also considered less effective considering that activities cannot be carried out directly due to the impact of the Pandemic which must maintain a distance. However, supervisors still try to carry out their duties as optimally as possible. What was conveyed by the supervisor through the results of the interview above was also strengthened by the narrative of the results of the interview with W that:

"During the spread of the Corona virus, supervisors often provided guidance through Whatsapp Grupp to PAI teachers related to learning activities that must be carried out during the pandemic. And various directions were conveyed by supervisors through the group. Although the learning activities carried out at home, the teacher still be obliged to create various reports and plan performance".

The implementation of remote education supervision through online mechanisms is not something that is carried out without reason. One of the factors is the constraints in the form of limitations to meet directly with the assisted teachers at school. This reason is reinforced by the 
existence of policies issued by the government to stay at home and also the imposition of Large-Scale Social Restrictions (PSBB) in a number of regions. This condition certainly provides restrictions on the steps and flexibility of supervisors in carrying out their supervisory duties. The decision that has been issued by the government to keep people from leaving the house is an effort to reduce the rate of transmission of the Covid-19 virus, so far there has not been any sign of its decline. This step was taken by the government to protect people from being exposed to this virus and not merely to keep people from staying at home. Therefore, supervisors also experience the excesses of this policy in carrying out their duties. On the one hand, supervisors are given the responsibility to maximize their work for the sake of educational development, but on the other hand, supervisors are faced with situations and conditions that make it impossible to directly carry out their work. Therefore, the step taken by supervisors is to shift the surveillance pattern to a remote distance from the network system by utilizing digital communication media that is currently developing.

In conducting supervisory activities on Islamic Education learning in schools carried out by teachers, school supervisors also plan. This plan is made to maximize surveillance performance during the
Pandemic. Supervision planning during the pandemic period must of course be more optimal considering this stage will determine the quality of the performance of the supervision that will be carried out. With regard to planning issues, as can be seen from the results of interviews with IMS as follows:

"The preparations made during the Pandemic were related to the task of supervising Islamic Education teachers in elementary schools in the target sub-districts, carried out by designing monthly performance plans or abbreviated as RKB. This $\mathrm{RKB}$ is made by the supervisor as well as by the teachers in planning activities that will be carried out over the next month. This $R K B$ is a basic reference for carrying out learning activities. The RKB made by the teacher is then checked and analyzed by the supervisor so that the learning that will be carried out is maximized even during the Pandemic era and with the PJJ system".

See description wa w ancara above, the planning process in the supervisory activities of the teaching in schools, is to make Monthly Activity Plan Format (RKB). This $\mathrm{RKB}$ is made by supervisors and also teachers in schools to determine what activities the education component will carry out in schools for the next one month. In this $\mathrm{RKB}$, the details of the activities of educators for the next month are also formulated, so that the teaching activities then refer to the RKB that was designed earlier as the guideline used. The existence of this $\mathrm{RKB}$ is a starting point in determining what activities will be carried out in relation to the supervision of education in schools. This stage is included 
in the planning aspect of education supervision management and its position is very important as a reference in the implementation of educational supervision activities for school supervisors.

Picture 1. Monthly Activity Plan Format (RKB).
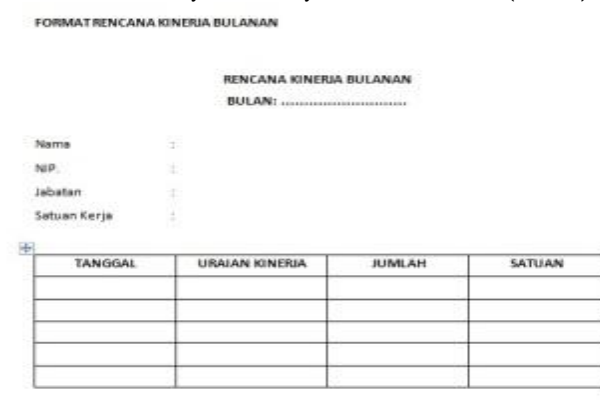

Atasson Longsung

Nap.

Source: RKB Supervisor

In connection with the making of the Monthly Activity Plan (RKB), U also stated that:

"In preparing learning activities and also as part of administration that must be made and submitted to the PAI Supervisor, PAI teachers are instructed by the Supervisor to make an RKB which contains a description. activities that will be carried out by the teacher for one month. These instructions are conveyed in the whatsapp group which includes a collection of Islamic Education teachers from all over the Subang district".

In an effort to carry out their duties, Supervisors often provide guidance to teachers through the Whatsapp Grupp media during the Pandemic period containing materials such as the technical implementation of online learning. Coaching is conducted via Whatsapp Grupp is technically run by the Trustees to undertake share or share content in it contains steps that must be done to maximize teachers in distance learning. The content of the content can be in the form of videos, link articles and other documents related to teaching problems.

Supervision activities carried out by supervisors are also carried out by analyzing the Daily Performance Report ( $\mathrm{LKH})$ made by teachers as stated in the results of the interview with $\mathrm{K}$ as follows:

"In carrying out their teaching duties at school, PAI teachers also make Daily Performance Reports (lkh) which submitted to the supervisor for inspection. The LKH contains a description of the activities that the teacher carries out every day in carrying out teaching assignments through the online system".

Picture 2. Daily Activity Report Format (LKH).

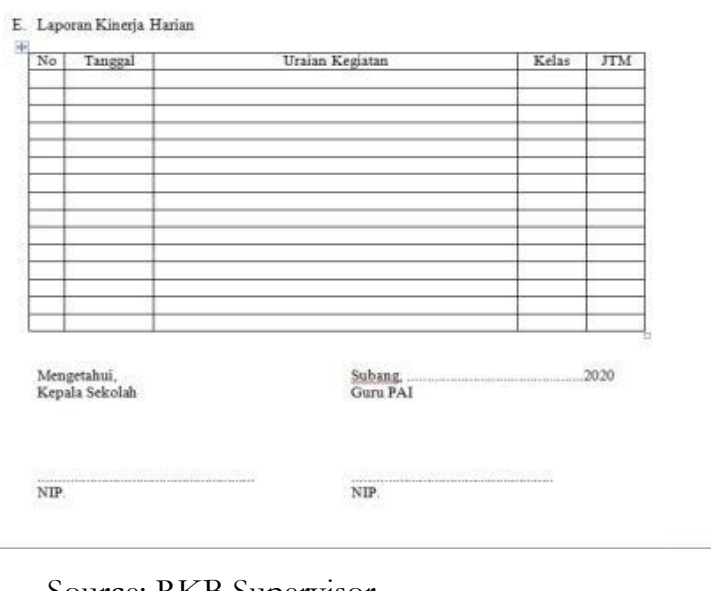

Source: RKB Supervisor

With regard to $\mathrm{LKH}$, it actually contains reports on the daily activities of the teacher for one month. This LKH is conveyed by the teacher to the supervisor as evidence that the teacher has taught. The supervisor in this case is responsible for checking the daily activities of the teacher through the $\mathrm{LKH}$ reported earlier. Everything that the 
teacher describes on the LKH sheet becomes a reference for supervisors in analyzing teacher performance in teaching.

Apart from making $\mathrm{LKH}$, another report that must also be made by teachers is a report on learning activities during the Covid-19 period. This can be seen in the results of the interview with $\mathrm{N}$ as follows:

"During learning during the Covid-19 period, the teacher made reports on learning activities at home to be submitted to the supervisor. This report is in the form of teaching activities carried out by teachers during the Pandemic period".

This home teaching activity report sheet is specifically designed to control teacher performance during the Pandemic so that teachers continue to carry out their teaching duties. Through this instrument, it is easier for supervisors to supervise their supervised teachers. In principle, everything that the teacher does in matters of teaching responsibility must be monitored by the education supervisor so that evaluation and follow-up can be carried out on these activities.

Picture 3. Home Study Activity Report.

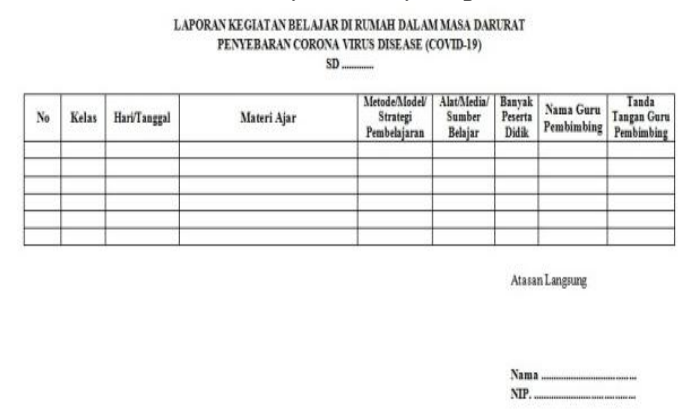

Source: RKB Supervisor

Then the form of evaluation carried out by the supervisor of the teaching carried out by PAI teachers in the Subang district is to make an Assessment of Employee Performance Targets. This can be seen in the results of the interview with IMS that:

"The form of evaluation carried out by supervisors in carrying out their supervisory duties is to make an assessment of employee performance targets or abbreviated as an assessment of SKP. This assessment is made to evaluate the teaching performance of teachers in schools as material for improving learning in the next period".

The task of school supervisors is also carried out by running an evaluation system of the entire series of teaching activities carried out by the teacher. The results of this evaluation in turn lead to an assessment of employee performance targets, both those that have been achieved and those that have not been achieved. Through this evaluation system, supervisors can determine teacher performance in carrying out teaching functions for students. In addition, from this evaluation, supervisors can analyze teacher performance and provide an assessment of the teacher's performance. In this case, the steps taken by the supervisor in carrying out his duties and responsibilities are deemed in accordance with the supervisory procedure in relation to the supervisor's performance.

The Quality of Islamic Education Learning at Elementary Schools in Subang District during the Covid-19 Pandemic

The learning process in schools experienced significant changes during the 
Covid-19 period that occurred in Indonesia.

This change can be seen from the learning system that was implemented where initially learning was carried out directly at school face-to-face had to be moved to learning at home with an online system to control the spread of the virus. The learning process with this online system by the PAI primary school teacher in Subang sub-district is deemed less effective considering that learning is carried out at home so that the teacher cannot directly monitor and guide the learning process. This is as stated from the results of the interview with $\mathrm{S}$ as follows:

"During the Covid-19 Pandemic, learning was carried out using the PJJ system or by using an online system. Learning with this system is considered not optimal because the teacher cannot control learning. In this case the dominant factor that can help learning during the Pandemic era for students is the parents of the students. However, not all parents of students are able to take full advantage of learning at home. This condition has an impact on the quality of learning that is not effective compared to direct learning in class".

The narrative of the results of the interview above provides information related to the lack of maximum learning that was carried out during the Pandemic period. The condition of teachers who are not directly with students when carrying out teaching is a separate obstacle faced. Teachers in this case have difficulty monitoring the learning activities of their students. Therefore, in an effort to maximize this learning, the role of parents who fully help teach students at home is needed. This is none other than intended so that students continue to have their rights to learn. Therefore, in maximizing this distance teaching, you cannot only rely on the role of the teacher, but the environment, especially the family, in this case parents of students, are an important part of contributing to efforts to maximize teaching during the Covid-19 Pandemic.

The results of other interviews regarding the quality of Islamic Education learning during the Pandemic period in the Subang sub-district primary school as can be seen in the results of the interview with $\mathrm{AN}$ are as follows:

"Learning PAI during the Covid-19 Pandemic, had to be done using the distance learning (PJJ) system. Learning with this system is considered less optimal than direct learning. Therefore, the support of parents at home is very belpful so that in principle PJJ should involve parents of students in an effort to maximize the learning process for students".

The narrative of the results of other interviews is as can be seen from the information given by $\mathrm{W}$ as follows: "It is undeniable that learning during the outbreak of the Corona Virus was not optimal. Teachers cannot teach as usual in class. What teachers can do in learning is among others by giving assignments to students and communicating them with parents of students in order to synergize in providing teaching for students".

Based on the description above, at least an illustration can be obtained related to 
learning in the Subang sub-district primary school environment during the Covid-19 Pandemic which was carried out using the PJJ system, namely distance learning. This learning is carried out with the mechanism of students and teachers remaining at their respective homes without making face-toface meetings given the rules of learning at home. Learning is also carried out by involving the parents of students. This learning is still considered not fully optimal in relation to the optimization of teaching in schools, so that in general, learning during the Covid-19 Pandemic that was carried out with the PJJ system was considered less effective compared to learning directly in the classroom considering that teachers were not fully able to oversee learning for students but by involving student's parents. Thus, the learning pattern carried out during this pandemic, namely by distance learning, has had an impact on the quality of learning. However, efforts to continue teaching should not be in vain, but must be seen as the right steps that can be applied to continue teaching in the midst of a pandemic situation.

\section{Primary School Supervisor Performance} Impacts on the Quality of Islamic Education Learning at Elementary Schools in Subang District

The performance of supervisors in carrying out their supervisory duties plays an important role in improving the quality of learning. This implies that efforts to improve the quality of learning are influenced by the quality factor of good supervisor performance. A good supervisor's performance is to carry out a whole series of supervisory activities in accordance with their main duties and functions optimally. However, as it is known that during the Pandemic period, learning activities were carried out in their respective homes in the sense that students and teachers did not meet face to face to carry out learning as usual in class. This condition then has an impact on the supervisory activities carried out by elementary school supervisors during the Covid-19 period in Subang sub-district which is carried out by remote surveillance methods through an online system or using digital media in this case Whatsapp Group, which is one of the existing applications. on a smartphone that supervisors can use to remain productive in carrying out their work even though they are done from home. Through the medium of Whatsapp Group, the school superintendent can directly share text, images, video, and link control contains content that teachers can see it on Smartphone respectively by using the application.

Apart from Whatsapp, there are actually many other applications that can be used, one of which is by using the Zoom Meeting media, which is one of the applications commonly used to conduct meetings with 
the capacity of many people in it who can participate. It is felt that the advancement of digital technology in such conditions can provide support for anticipatory steps that can be used so that surveillance activities can continue to the fullest. Although not all educational resources have good mastery in the operation of various applications on smartphones. However, even in the midst of a difficult situation such as a pandemic outbreak, the education process must continue from various aspects such as supervision, teaching and so on.

Furthermore, in relation to monitoring activities through a remote system, Supervisors are also supported by the existence of various supporting reports such as LKH, RKB, Home Study Activity Reports, Employee Performance Target Assessment and so on. These various report formats were made to maximize the supervisory activities carried out by the supervisors of Islamic Education subjects in the Subang sub-district elementary school.

\section{DISCUSSION}

Looking at the description of the research results as stated in the sub-points above, information can be obtained that the performance of primary school supervisors in Subang sub-district during the Covid-19 Pandemic was carried out using a remote surveillance system or through an online system using Whatsapp Group media.
Even though with all the limitations of activities to carry out direct supervision given the implementation of social distancing and physical distancing as well as the existence of a home learning system, Supervisors still try their best to carry out their supervisory duties by carrying out various activities through the Whatsapp Group such as conducting coaching, instructing teachers to make certain reports such as making LKH, RKB, Reports of Home Study Activities at Mada Covid-19, and Assessment of Employee Performance Targets and various other activities. However, surveillance activities during the Covid-19 Pandemic in the elementary school environment in Subang sub-district for PAI subjects generally did not run optimally considering the obstacles faced in the remote surveillance system. Nevertheless, what the elementary school supervisors in Subang sub-district were doing was actually very appropriate in trying to take advantage of all available forms of media in order to maximize their performance in terms of supervising the PAI teachers they coached (Wajdi et al., 2020).

In addition, if you pay close attention to what supervisors are doing in the process of supervising education in elementary schools in Subang sub-district, when seen from the pattern implemented, it refers to the 
supervision procedure, this can be identified from the planning that is carried out through the Monthly Activity Plan (RKB). This $\mathrm{RKB}$ is the basis of reference in carrying out educational supervision activities. Then also in terms of implementation can also be identified from the format of the Daily Performance Report $(\mathrm{LKH})$ which becomes a record for activities carried out in carrying out supervision. Furthermore, supervisors also carry out an evaluation function and provide an assessment of teacher performance in carrying out their teaching duties. These steps are part of the management function of education supervision in schools. Therefore, it needs to be understood that even in the midst of a pandemic situation, education supervision can still be carried out referring to the education supervision management procedure (Aswasulasikin, 2020; Hasanah et al., 2020).

Another aspect that can be analyzed from education supervision at primary schools in the Subang sub-district is that surveillance activities during the Covid-19 Pandemic which were carried out using a remote system had a different pattern from direct supervision. This teaching pattern then has an impact on the quality of learning that is produced, especially from the aspect of the substance of the material conveyed to students and the mastery of student material is part of a number of factors that illustrate that the quality of learning produced by students is different from the direct learning system.

However, the supervision mechanism carried out in the Subang sub-district primary school needs to be seen as part of the effort to carry out educational functions amid the threat of the Covid-19 pandemic. Therefore various digital media such as Whatsapp Group, Zoom Meeting and so become an alternative media that can be maximized in the oversight of education. In addition, to really ensure that the supervisory function is properly carried out, supervisors need to occasionally carry out direct supervision while still paying attention to health protocols so that their supervisory management functions can be optimized.

\section{CONCLUSION}

Based on the results of research and discussion, in this study it can be concluded that the performance of elementary school supervisors during the Covid-19 Pandemic in Subang sub-district was carried out using a remote surveillance system or through an online system using Whatsapp Group media - Various supervisory activities carried out through the Whatsapp Group include coaching activities, instructing teachers to make certain reports such as making LKH, RKB, Reports on Home Study Activities during the Covid-19 period, and Assessment of Employee Performance Targets and various other activities. These various report 
formats were made to maximize the supervisory activities carried out by the supervisors of Islamic Education subjects in the Subang sub-district elementary school. Surveillance activities during the Covid-19 Pandemic which were carried out with a remote system were an alternative step that could be applied in carrying out the supervisory function in schools in a pandemic situation, although the pattern of surveillance through a remote system still could not completely replace the direct supervision pattern. Therefore, to ensure that supervisory activities run optimally, the supervision pattern needs to be carried out directly from time to time while still implementing health protocols so that the supervisory management functions and the quality of student learning are optimal.

\section{REFERENCES}

Ahmad Jaelani, Hamdan Fauzi, Heti Aisah, Q. Y. Z. (2020). Penggunaan Media Online Dalam Proses Kegiatan Belajar Mengajar PAI di Masa Pandemi Covid-19. Jurnal Ikatan Alumni PGSD UNARS, 8(1), 12-24.

Al-Kiyumi, A., \& Hammad, W. (2020). Preparing Instructional Supervisors for Educational Change: Empirical Evidence From the Sultanate of Oman. SAGE Open, 10(2), 2158244020935905.

https://doi.org/10.1177/215824402 0935905

Arifa, F. N. (2020). Tantangan Pelaksanaan Kebijakan Belajar Dari Rumah Dalam Masa Darurat Covid-19.
Bidang Kesejabteraan Sosial INFO Singkat: Info Singkat;Kajian Singkat Terbadap Isu Aktual Dan Strategis, XII(7), 13-18.

Aswasulasikin, A. (2020). Persepsi Mahasiswa Terhadap Kuliah Daring di Masa Pandemi Corona Virus Disease (COVID-19). SALAM: Jurnal Sosial dan Budaya Syar-i, 7(8), Article 8. https://doi.org/10.15408/sjsbs.v7i8 .15734

Beddu, S. (2020). Fungsi Pengawasan dalam Tinjauan Pendidikan Islam. Jurnal Ash-Sababah, 6(1), 40-47.

Dewi, W. A. F. (2020). Dampak Covid-19 terhadap implementasi pembelajaran daring di Sekolah Dasar. Edukatif: Jurnal Ilmu Pendidikan, 2(1), 55-61.

Echols, H. S. dan J. M. (2014). Kamus Inggris Indonesia. PT. Gramedia.

Fadhli, M. (2016). Manajemen Peningkatan Mutu Pendidikan. Jurnal Itqon, VII(1), 103-113.

Faiqoh, D. (2019). Supervisi Kepala Madrasah Dalam Meningkatkan Profesionalisme Guru. Jurnal Kependidikan, 7(1), 98-110.

Gusmadi. (2014). Pelaksanaan Manajemen Pengawasan Pendidikan Agama Islam di SMA Negeri di Kabupaten Tanah Datar. Jurnal Al-Fikrah, II(2), 130-142.

Habibullah, A. (2013). Kinerja Pengawas Pendidikan Agama Islam. Jurnal EDUKASI, 11(06), 46-64.

Hasanah, A., Lestari, A. S., Rahman, A. Y., \& Daniel, Y. I. (2020, May 1). Analisis aktivitas belajar daring mahasiswa pada pandemi Covid-19 [Workshop]. KTI masa WFH LP2M. http://digilib.uinsgd.ac.id/30565/ 
Hawkins, J., \& Dulewicz, V. (2009). Relationships between Leadership Style, the Degree of Change Experienced, Performance and Follower Commitment in Policing. Journal of Change Management, 9(3), 251-270.

https://doi.org/10.1080/146970109 03125498

Iskandar, D., \& Wibowo, U. B. (2016). Peran Pengawas Pendidikan dalam Peningkatan Mutu Pendidikan di Kabupaten Bima Privinsi Nusa Tenggara Barat. Jurnal Penelitian Pendidikan, 9(2), 179-195.

Klijn, E. H., Boer, N. de, \& Eshuis, J. (2020). Leading frontline enforcers: How supervisors' leadership style impacts inspectors' enforcement style. Public Management Review, O(0), $1-20$.

https://doi.org/10.1080/14719037. 2020.1833610

Mangkunegara, A. A. A. P. (2010). Manajemen Sumber Daya Manusia Perusabaan. Remaja Rosdakarya.

Mesiono, M. (2019). The Influence of Job Satisfaction on the Performance of Madrasah Aliyah (Islamic Senior High School) Teachers. Tadris: Jurnal Keguruan Dan Ilmu Tarbiyah, 4(1), 107-116.

https://doi.org/10.24042/tadris.v4i 1.4388

Muhammad Nur, Cut Zahri Harun, S. I. (2016). Manajemen Sekolah Dalam Meningkatkan Mutu Pendidikan Pada Sdn Dayah Guci Kabupaten Pidie. JURNAL Administrasi Pendidikan Pascasarjana Universitas Syiah Kuala, 4(1), 93-103.

Muhardi. (2004). Kontribusi Pendidikan Dalam Meningkatkan Kualitas Bangsa Indonesia. Mimbar: Jurnal
Sosial Dan Pembangunan, XX(4), 478492.

Mulyasana, D. (2011). Pendidikan Bermutu Dan Berdaya Saing. Remaja Rosdakarya.

Munir. (2009). Pembelajaran Jarak Jaub berbasis Teknologi Informasi dan Komunikasi (TIK). Alfabeta.

Munjiat, S. M. (2020). Implementation of Islamic Religious Education Learning in Higher Education on The Pandemic Period. Nazhruna: Jurnal Pendidikan Islam, 3(2), 285295.

https://doi.org/10.31538/nzh.v3i2. 757

Muslimin. (2016). Evaluasi Kinerja Pengawas Sekolah Menengah Pertama Negeri. Jurnal Manajemen Pendidikan, 15(2), 129-133.

Napitupulu, R. M. (2020). Dampak Pandemi Covid-19 Terhadap Kepuasan Pembelajaran Jarak Jauh. Jurnal Inovasi Teknologi Pendidikan, 7(1), 2333.

https://doi.org/10.21831/jitp.v7i1.3 2771

Nurmala, M. A. dan B. (2019). Efektivitas Pelaksanaan Supervisi Oleh Pengawas Dalam Meningkatkan Kompetensi Profesional Guru IPA pada SMP Negeri 3 Ingin Jaya Kabupaten Aceh Besar. Jurnal Administrasi Pendidikan, 7(1), 26-34.

Pujilestari, Y. (2020). Dampak Positif Pembelajaran Online Dalam Sistem Pendidikan Indonesia Pasca Pandemi Covid-19. 'ADALAH, 4(1), Article 1. https://doi.org/10.15408/adalah.v4i 1.15394

Rahmad, N. dan N. (2018). Pelaksanaan Supervisi Oleh Kepala Sekolah dan Pengawas Sekolah. Jurnal Manajemen, 
Kepemimpinan, Dan Supervisi Pendidikan, 3(1), 137-148.

Siahaan, A., Rafida, T., \& Batubara, K. (2020). Influence of Madrasah Head Leadership, Motivation and Madrasah Culture on Teacher Performance in Madrasah Aliyah Model 2 Medan. Budapest International Research and Critics Institute (BIRCIJournal): Humanities and Social Sciences, 3, 2174-2182. https://doi.org/10.33258/birci.v3i3. 1150

Solikah, A. (2014). Strategi Peningkatan Mutu Pembelajaran pada Sekolah Unggulan: Studi Multi Situs di MI Darul Muta'alimin Patianrowo Nganjuk, MI Muhammadiyah 1 Pare dan SD Katolik Frateran 1 Kota Kediri. Jurnal Didaktika Religia, 2(1), 175-212.

Sudrajat, C. J., Agustin, M., Kurniati, L., \& Karsa, D. (2020). Strategi Kepala TK Dalam Meningkatkan Mutu Pendidikan Pada Masa Pandemi Covid 19. Jurnal Obsesi: Jurnal Pendidikan Anak Usia Dini, 5(1), 509. https://doi.org/10.31004/obsesi.v5i 1.582

Tahir, Abd. W. (2017). Implementasi Manajemen Berbasis Madrasah dalam Peningkatan Mutu. Jurnal Lentera Pendidikan, 20(53), 240-249.

Wajdi, M. B. N., Ubaidillah, M. B., Mulyani, S., Anwar, K., Istiqomah, L., Rahmawati, F., Hikmawati, S. A., Ningsih, D. R., \& Rizal, H. S. (2020). Pendampingan Redesign Pembelajaran Masa Pandemi Covid19 bagi Tenaga Pendidik di Lembaga Pendidikan berbasis Pesantren di Jawa Timur. Engagement: Jurnal Pengabdian Kepada Masyarakat, 4(1),
266-277.

https://doi.org/10.29062/engageme nt.v4i1.193

Wibowo, D. I. dan U. B. (2016). Peran Pengawas Pendidikan Dalam Peningkatan Mutu Pendidikan SMP di Kabupaten Bima Provinsi Nusa Tenggara Barat. Jurnal Penelitian Ilmu Pendidikan, 9(2), 179-195.

Yustiani. (2013). Kinerja Pengawas Madrasah Di Provinsi Daerah Yogyakarta. Jurnal Analisa, 20(1), 115-130. 